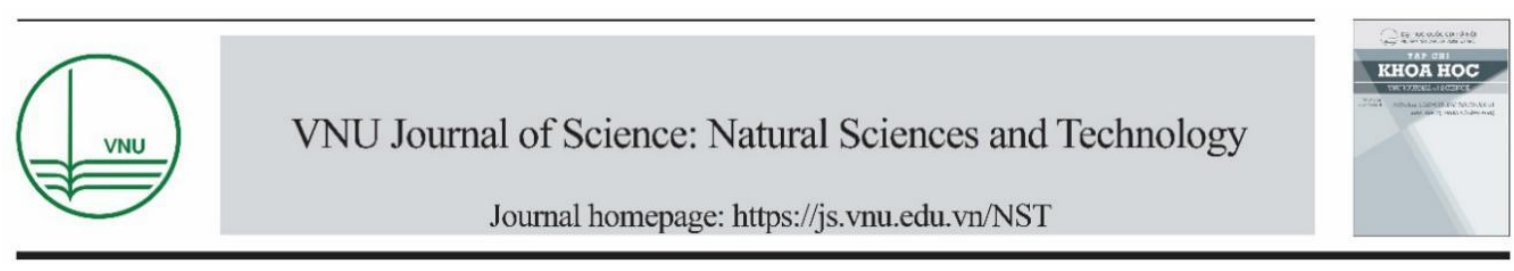

Original Article

\title{
Palladium(II) Complex with Tridentate Ligand Containing Pyrenyl Core
}

\author{
Nguyen Minh Hai ${ }^{1, *}$, Tran Thi Tam Thu ${ }^{1}$, Dinh Thi Thao ${ }^{2}$ \\ ${ }^{1}$ Faculty of Chemistry, VNU University of Science, 19 Le Thanh Tong, Hanoi, Vietnam \\ ${ }^{2}$ Department of Chemistry, Faculty of Science, Army Academy 1, Co Dong, Son Tay, Hanoi, Vietnam
}

Received 15 July 2019

Revised 28 July 2019; Accepted 29 July 2019

\begin{abstract}
A series of ligands containing pyrenyl core which are PyEt1, PyEt2, and PyEt3 have been successfully synthesized. PyEt2, a bidentate ligand and PyEt3, a tridentate ligand were used to prepared $\mathrm{Pd}(\mathrm{II})$ complexes by reactions with $\mathrm{PdCl}_{2}\left(\mathrm{CH}_{3} \mathrm{CN}\right)_{2}$. The titled compounds displayed intriguing geometries around the central palladium atoms. ${ }^{1} \mathrm{H}-\mathrm{NMR}$ results showed that palladium in Pd-PyEt3 adopts a five-coordinate configuration.
\end{abstract}

Keywords: Pyrene, palladium, five coordination.

\section{Introduction}

Polycyclic aromatic hydrocarbons (PAH) are a class of compounds that possess extended $\pi$ conjugated systems. This unique structural property renders PAHs strong absorption and emission in visible region. However, PAH-based research is often limited by their low solubility in common organic solvents. Functionalization of pyrene by appending solubilizing groups that contain donor atoms like nitrogen proved to be an effective strategy to overcome its poor solubility and open up its coordination chemistry [1-4].

\footnotetext{
* Corresponding author.

Email address: minhhai.nguyen@ hus.edu.vn

https://doi.org/10.25073/2588-1140/vnunst.4919
}

Palladium(II) complexes are well-known for its stable $\mathrm{d}^{8}$ square-planar geometries. Large crystal field stabilization is attributed to this preferential structure. Other coordination modes rather than square-planar would be of unusually fundamental importance [5]. The ligands with multiple donor atoms are expected to give rise such structures.

In the present work, we describe the syntheses and NMR structural determination of a series of ligands which contain pyrenyl moiety and their interactions with palladium(II) ion. Our 
results show that PyEt3 can bind to the Pd(II) ion to form an unusual five-coordinate complex.

\section{Experimental}

\subsection{Materials and instruments}

All the chemical reagents used in the experiments were obtained from commercial sources as guaranteed-grade reagents and used without further purification.

The FT-IR spectra of the complexes were measured on a FT-IR 8700 infrared spectrophotometer $\left(4000-400 \mathrm{~cm}^{-1}\right)$ in $\mathrm{KBr}$ pellets. The ${ }^{1} \mathrm{H}-\mathrm{NMR}$ spectra were recorded on a Bruker-500MHz spectrometer in $\mathrm{CDCl}_{3}$ solution at $300 \mathrm{~K}$.

\subsection{Synthesis of PyEt1}

To a $10 \mathrm{ml}$ ethanolic solution of pyrene-1carbaldehyde $(0.100 \mathrm{~g}, 0.435 \mathrm{mmol})$ was added $\mathrm{N}, \mathrm{N}$-diethylethylenediamine $\quad(0.166 \mathrm{~g}$, $1.426 \mathrm{mmol})$. The resulting mixture was stirred and refluxed for $5 \mathrm{~h}$. The solvent was reduced to dryness and then a large amount of water was used for washing to produce a yellow semi-solid. Yield: $0.12 \mathrm{~g}(85 \%)$.

Data for PyEt1: IR: $v_{\max } / \mathrm{cm}^{-1}=3606(\mathrm{w})$, 2964 (w), 1624 (s), 1597 (m), 1449 (m), 1201 (s), 1176 (s), 1060 (s), 1143 (s), 844 (s), $713(\mathrm{~m}) ;{ }^{1} \mathbf{H}$ NMR $\left(\mathrm{CDCl}_{3}, \delta \mathrm{ppm}\right): 9.33$ (s, $1 \mathrm{H}, \mathrm{H}_{\mathrm{e}}$, imine), $8.91\left(\mathrm{~d}, J=9 \mathrm{~Hz}, 1 \mathrm{H}, \mathrm{H}_{10}\right.$, pyrenyl $), 8.52(\mathrm{~d}, J=$ $8.0 \mathrm{~Hz}, 1 \mathrm{H}, \mathrm{H}_{2}$, pyrenyl) $8.23-8.02(\mathrm{~m}, 7 \mathrm{H}$, $\mathrm{H}_{3,4,5,6,7,8,9}$, pyrenyl), 3.95 (t, $J=7.0 \mathrm{~Hz}, 2 \mathrm{H}, \mathrm{H}_{\mathrm{a}}$, $\left.\mathrm{CH}_{2}\right), 2.94\left(\mathrm{t}, J=7.0 \mathrm{~Hz}, 2 \mathrm{H}, \mathrm{H}_{\mathrm{b}}, \mathrm{CH}_{2}\right), 2.69$ (q, $\left.J=7.0 \mathrm{~Hz}, 4 \mathrm{H}, \mathrm{H}_{\mathrm{c}}, \mathrm{CH}_{2}\right), 1.11(\mathrm{t}, J=7.0 \mathrm{~Hz}, 6 \mathrm{H}$, $\left.\mathrm{H}_{\mathrm{d}}, \mathrm{CH}_{3}\right)$.

\subsection{Synthesis of PyEt2}

To a yellow solution of PyEt1 (0.115g, $0.360 \mathrm{mmol})$ in $\mathrm{CH}_{2} \mathrm{Cl}_{2} /$ methanol $(10 / 5 \mathrm{~mL})$ was added $\mathrm{NaBH}_{4} \quad(0.760 \mathrm{~g}, 2.000 \mathrm{mmol})$. The mixture was stirred overnight, then dried and washed with water to give a pale yellow product. Yield: $0.10 \mathrm{~g}(83 \%)$.
Data for PyEt2: IR: $v_{\max } / \mathrm{cm}^{-1}=3294(\mathrm{w})$, 1600 (s), 1587 (s), 1454 (s), 1382 (m), 1066 (m), 846 (s), $756(\mathrm{~s}) ;{ }^{1} \mathbf{H}$ NMR $\left(\mathrm{CDCl}_{3}, \delta \mathrm{ppm}\right): 8.37$ $\left(\mathrm{d}, J=9 \mathrm{~Hz}, 1 \mathrm{H}, \mathrm{H}_{10}\right.$, pyrenyl), 8.18-7.97 (m, $8 \mathrm{H}$, $\mathrm{H}_{2,3,4,5,6,7,8,9}$, pyrenyl), 4.50 (s, $\left.2 \mathrm{H}, \mathrm{H}_{\mathrm{f}}, \mathrm{CH}_{2}\right), 2.85$ $\left(\mathrm{t}, J=6.0 \mathrm{~Hz}, 2 \mathrm{H}, \mathrm{H}_{\mathrm{a}}, \mathrm{CH}_{2}\right), 2.62(\mathrm{t}, J=6.0 \mathrm{~Hz}$, $\left.2 \mathrm{H}, \mathrm{H}_{\mathrm{b}}, \mathrm{CH}_{2}\right), 2.49$ (q, J = 7.0Hz, $4 \mathrm{H}, \mathrm{H}_{\mathrm{c}}, \mathrm{CH}_{2}$ ), $0.99\left(\mathrm{t}, J=7.0 \mathrm{~Hz}, 6 \mathrm{H}, \mathrm{H}_{\mathrm{d}}, \mathrm{CH}_{3}\right)$.

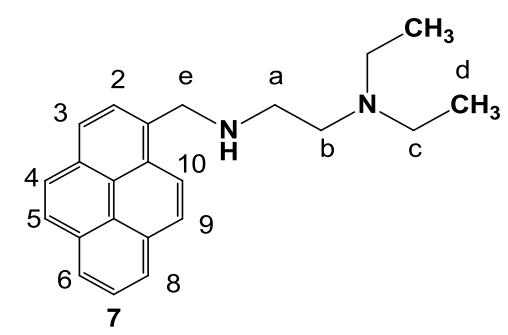

\subsection{Synthesis of PyEt3}

0.100g (0.304mmol) of PyEt2 was dissolved in $10 \mathrm{~mL}$ of $\mathrm{CH}_{3} \mathrm{CN}$ in a $100 \mathrm{~mL}$ round bottom flask. To the resulting solution was added $0.050 \mathrm{~g}$ $(0.304 \mathrm{mmol})$ of 2 -(chloromethyl) pyridine hydrochloride and $1.000 \mathrm{~g}$ of $\mathrm{K}_{2} \mathrm{CO}_{3} \cdot 1.5 \mathrm{H}_{2} \mathrm{O}$. The mixture was refluxed for $72 \mathrm{~h}$ in the absence of light. The solvent was then removed by rotary evaporation. Extraction with $\mathrm{CH}_{2} \mathrm{Cl}_{2}$ yielded a brownish solid. Yield: $0.090 \mathrm{~g}(71 \%)$.

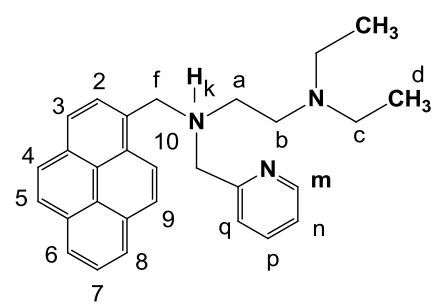

Data for PyEt3: IR: $v_{\max } / \mathrm{cm}^{-1}=3039(\mathrm{w})$, 1649 (s), 1587 (s), 1431 (s), 1373 (m), 1066 (m), 844 (s), 756 (s). ${ }^{1} \mathbf{H}$ NMR $\left(\mathrm{CDCl}_{3}, \delta\right.$ ppm): 8.59 $\left(\mathrm{d}, J=9 \mathrm{~Hz}, 1 \mathrm{H}, \mathrm{H}_{10}\right.$, pyrenyl), 8.47 (dd, $J=6 \mathrm{~Hz}$,

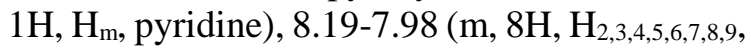
pyrenyl), 7.55 (dt, $J=6 \mathrm{~Hz}, 1 \mathrm{H}, \mathrm{H}_{\mathrm{n}}$, pyridine), $7.43\left(\mathrm{~d}, J=6 \mathrm{~Hz}, 1 \mathrm{H}, \mathrm{H}_{\mathrm{p}}\right.$, pyridine), 7.07 (dt, $J=$ $6 \mathrm{~Hz}, 1 \mathrm{H}, \mathrm{H}_{\mathrm{q}}$, pyridine), $4.39\left(\mathrm{~s}, 2 \mathrm{H}, \mathrm{H}_{\mathrm{f}}, \mathrm{CH}_{2}\right.$ ), $3.87\left(\mathrm{~s}, 2 \mathrm{H}, \mathrm{H}_{\mathrm{g}}, \mathrm{CH}_{2}\right), 2.78\left(\mathrm{t}, J=6.0 \mathrm{~Hz}, 2 \mathrm{H}, \mathrm{H}_{\mathrm{a}}\right.$, $\mathrm{CH}_{2}$ ), 2.72 (t, $\left.J=6.0 \mathrm{~Hz}, 2 \mathrm{H}, \mathrm{H}_{\mathrm{b}}, \mathrm{CH}_{2}\right), 2.46$ (q, $\left.J=7.0 \mathrm{~Hz}, 4 \mathrm{H}, \mathrm{H}_{\mathrm{c}}, \mathrm{CH}_{2}\right), 0.93(\mathrm{t}, J=7.0 \mathrm{~Hz}, 6 \mathrm{H}$, $\mathrm{H}_{\mathrm{d}}, \mathrm{CH}_{3}$ ). 


\subsection{Synthesis of Pd-PyEt2}

To a $\mathrm{CH}_{2} \mathrm{Cl}_{2}$ solution of PyEt2 $(0.010 \mathrm{~g}$, $0.030 \mathrm{mmol})$ was added $\mathrm{PdCl}_{2}\left(\mathrm{CH}_{3} \mathrm{CN}\right)_{2}$. $(0.008 \mathrm{~g}, 0.031 \mathrm{mmol})$. A clear yellowish solution was obtained after $4 \mathrm{~h}$ of stirring at room temperature. The solvent was reduced and excess hexane was added to afford the titled product. Yield: $0.011 \mathrm{~g}(72 \%)$.

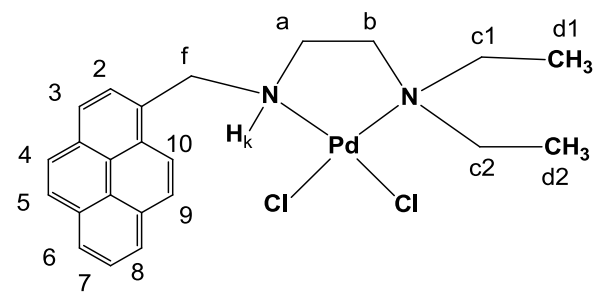

Data for Pd-PyEt2: IR: $v_{\max } / \mathrm{cm}^{-1}=3041$ (w), 1641 (s), 1597 (s), 1434 (s), 1383 (m), 1069 (m), 843 (s), 759 (s). ${ }^{1} \mathbf{H}$ NMR $\left(\mathrm{CDCl}_{3}, \delta\right.$ ppm): $8.67\left(\mathrm{~d}, 1 \mathrm{H}, \mathrm{H}_{10}\right.$, pyrenyl), 8.38-8.11 (m, $8 \mathrm{H}$, $\mathrm{H}_{2,3,4,5,6,7,8,9}$, pyrenyl), 6.07 (m, $2 \mathrm{H}, \mathrm{H}_{\mathrm{f}}, \mathrm{CH}_{2}$ ), $5.34\left(\mathrm{~d}, 2 \mathrm{H}, \mathrm{H}_{\mathrm{a}}, \mathrm{CH}_{2}\right), 4.50\left(\mathrm{t}, 2 \mathrm{H}, \mathrm{H}_{\mathrm{b}}, \mathrm{CH}_{2}\right), 2.81$ (q, $2 \mathrm{H}, \mathrm{H}_{\mathrm{c} 1}, \mathrm{CH}_{2}$ ), 2.61 (q, 2H, $\left.\mathrm{H}_{\mathrm{c} 2}, \mathrm{CH}_{2}\right), 1.49$ (t, $\left.3 \mathrm{H}, \mathrm{H}_{\mathrm{d} 1}, \mathrm{CH}_{3}\right), 1.49$ (t, $3 \mathrm{H}, \mathrm{H}_{\mathrm{d} 2}, \mathrm{CH}_{3}$ ).

\subsection{Synthesis of Pd-PyEt3}

The compounds were prepared following the procedures for Pd-PyEt2, except that PyEt3 was used instead of PyEt2. Yield: 77\%.

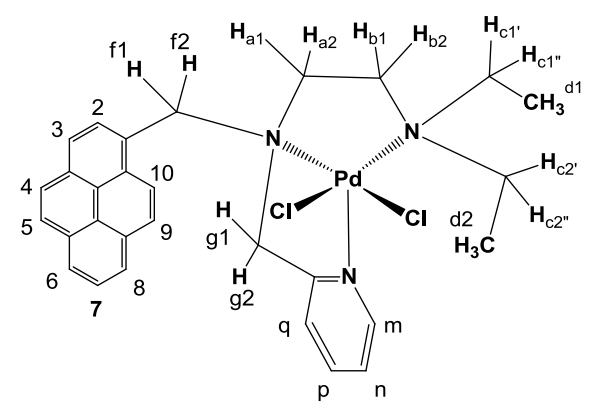

Data for Pd-PyEt3: IR: $v_{\max } / \mathrm{cm}^{-1}=3032$ (w), 1651 (s), 1590 (s), 1434 (s), 1376 (m), 1069 (m), 847 (s), 756 (s). ${ }^{1} \mathbf{H}$ NMR $\left(\mathrm{CDCl}_{3}, \delta \mathrm{ppm}\right)$ : $9.29\left(\mathrm{~d}, 1 \mathrm{H}, \mathrm{H}_{10}\right.$, pyrenyl), 8.88-7.83 (m, 8H, $\mathrm{H}_{2,3,4,5,6,7,8,9}$, pyrenyl), 7.60 (d, $1 \mathrm{H}, \mathrm{H}_{\mathrm{m}}$, pyridine), $6.49\left(\mathrm{~d}, 1 \mathrm{H}, \mathrm{H}_{\mathrm{q}}\right.$, pyridine $), 6.46\left(\mathrm{t}, 1 \mathrm{H}, \mathrm{H}_{\mathrm{p}}\right.$, pyridine), $5.94\left(\mathrm{t}, 1 \mathrm{H}, \mathrm{H}_{\mathrm{n}}\right.$, pyridine $), 5.42(\mathrm{~m}, 2 \mathrm{H}$, $\left.\mathrm{H}_{\mathrm{f} 1, \mathrm{f} 2}, \mathrm{CH}_{2}\right), 5.12\left(\mathrm{~m}, 2 \mathrm{H}, \mathrm{H}_{\mathrm{g} 1, \mathrm{~g} 2}, \mathrm{CH}_{2}\right), 4.55$ (d, $\left.1 \mathrm{H}, \mathrm{H}_{\mathrm{a} 1}, \mathrm{CH}_{2}\right), 4.43\left(\mathrm{t}, 1 \mathrm{H}, \mathrm{H}_{\mathrm{a} 2}, \mathrm{CH}_{2}\right), 3.91(\mathrm{~m}$, $\left.1 \mathrm{H}, \mathrm{H}_{\mathrm{cl}}, \mathrm{CH}_{2}\right), 3.70\left(\mathrm{t}, 1 \mathrm{H}, \mathrm{H}_{\mathrm{b} 1}, \mathrm{CH}_{2}\right), 3.44(\mathrm{~m}$, $1 \mathrm{H}, \mathrm{H}_{\mathrm{c} 1}$ ", $\left.\mathrm{CH}_{2}\right), 3.10\left(\mathrm{~d}, 1 \mathrm{H}, \mathrm{H}_{\mathrm{b} 2}, \mathrm{CH}_{2}\right), 3.02(\mathrm{~m}$, $\left.1 \mathrm{H}, \mathrm{H}_{\mathrm{c} 2}, \mathrm{CH}_{2}\right), 2.56\left(\mathrm{~m}, 1 \mathrm{H}, \mathrm{H}_{\mathrm{c} 2}\right.$ ", $\left.\mathrm{CH}_{2}\right), 1.66(\mathrm{t}$, $\left.3 \mathrm{H}, \mathrm{H}_{\mathrm{dl}}, \mathrm{CH}_{3}\right), 1.48\left(\mathrm{t}, 3 \mathrm{H}, \mathrm{H}_{\mathrm{dl}}, \mathrm{CH}_{3}\right)$.

\section{Results and discussion}

\subsection{Syntheses}

The ligand PyEt1 was synthesized by a condensation reaction between pyrene-1carbaldehyde and N,N-diethylethelenediamine in good yields. Reduction of imine fragment in PyEt1 by sodium borohydride produced PyEt2 with robust C-N single bonds. A picolyl part was introduced by the reflux of PyEt2 in acetonitrile over $72 \mathrm{~h}$. The three ligands are pale yellow semisolids and very well-soluble in common organic solvents like $\mathrm{CH}_{2} \mathrm{Cl}_{2}, \mathrm{CHCl}_{3}$, acetone, THF....
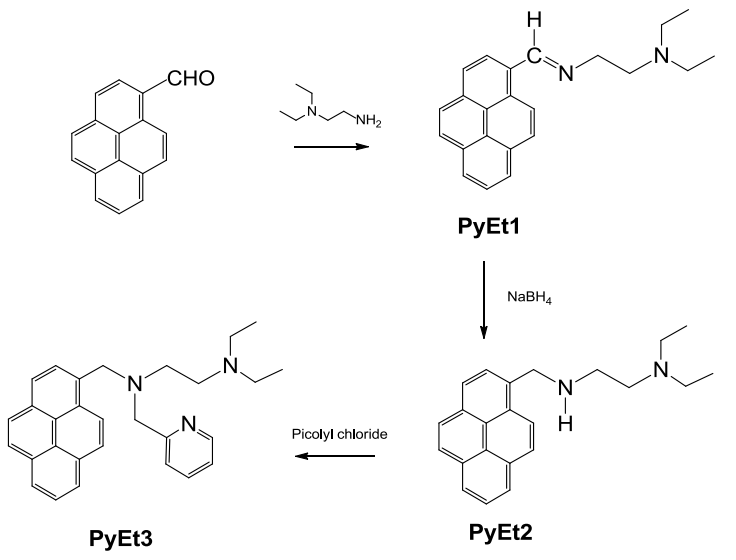

Scheme 1. Synthetic scheme of the ligands.

The palladium complexes of PyEt2 and PyEt3 were prepared by simple mixing of $\mathrm{PdCl}_{2}\left(\mathrm{CH}_{3} \mathrm{CN}\right)_{2}$ with the two ligands, respectively. The weakly coordinating ligand, $\mathrm{CH}_{3} \mathrm{CN}$, was easily displaced to yield the complexes in high yields. The complexes are well-soluble in $\mathrm{CHCl}_{3}$ but sparingly soluble in hexane. Numerous attempts to obtain the crystalline solids of Pd-PyEt2 and Pd-PyEt3 suitable for X-ray single crystal diffraction failed. 
The ligands and the complexes were characterized by infrared spectroscopy. As the results indicated, the strong band at $1624 \mathrm{~cm}^{-1}$ confirmed the formation of PyEt1. The disappearance of the band in PyEt2 implied that the $\mathrm{C}=\mathrm{N}$ bond was completely reduced. The infrared spectra of PyEt3 and the two complexes Pd-PyEt2 and Pd-PyEt3 showed characteristic bands of the aromatic moieties.
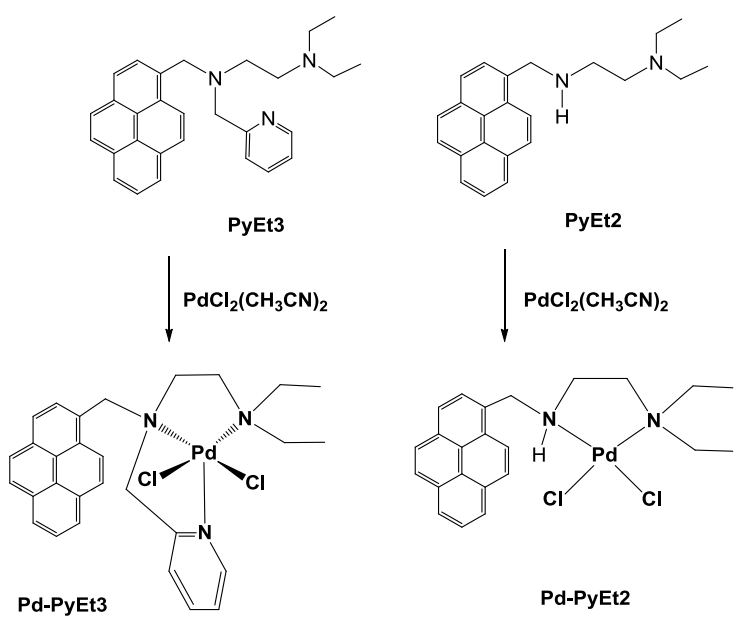

Scheme 2. Synthetic scheme of the complexes.

\subsection{Characterization of complexes by ${ }^{l} H-N M R$}

The distinct differences between the ${ }^{1} \mathrm{H}$ NMR spectrum of PyEt2 and that of Pd-PyEt2 (Figure 2) are noted. The signals responsible for methylene groups of pyrenyl rings $(6.07 \mathrm{ppm})$ and ethylenediamine fragments $(5.34 \mathrm{ppm}$ and $4.50 \mathrm{ppm})$ in the complex are down field shifted, compared to those of the free ligand. This evidence confirms the presence of metal atom in connection with two nitrogen donor atoms. The patterns of these signals also change significantly due to the rigridity of the chelate ring formed upon the complexation. The pyrenyl methylene protons give no longer a singlet but a complex multiplet due to spin coupling with its surrounding $\mathrm{N}-\mathrm{H}$ and $\mathrm{N}-\mathrm{CH}_{2}$ protons. More interestingly, the signals for ethylenediamine protons which are assigned for the two triplets in PyEt2, are a doublet and a triplet in Pd-PyEt2. This is reasonable in light of the fact that the four protons are now fixed and forms different dihedral angles with carbon atoms which in turn give rise to different coupling constant values. Due to effective inversion of substituents around nitrogen atom, the two ethyl groups in PyEt2 gave a set of signals including a triplet and a quartet. However, because of the coordination of palladium atom in Pd-PyEt2, the inversion is now firmly locked, making two ethyl groups chemically inequivalent. This is evidenced by the apprearance of two sets of triplet and quartet in the up field region.

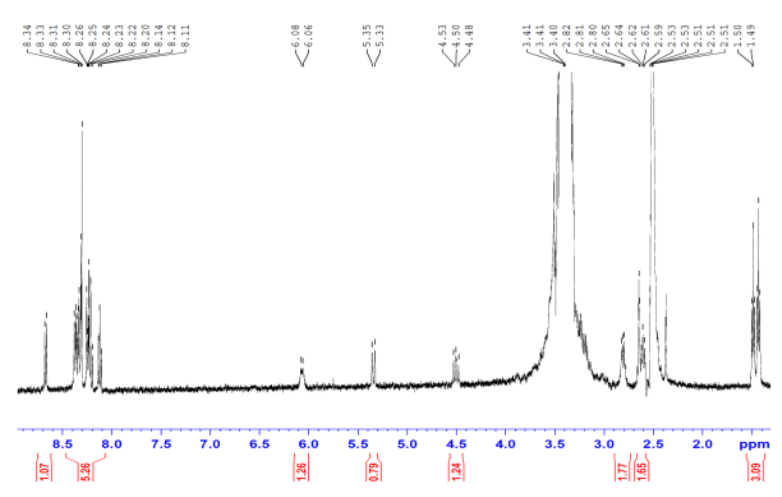

Figure 1. ${ }^{1} \mathrm{H}$ NMR spectrum of Pd-PyEt2 in $\mathrm{CDCl}_{3}$.

The ${ }^{1} \mathrm{H}-\mathrm{NMR}$ spectrum of palladium complex of PyEt3 (Figure 3) is much more complicated than that of PyEt3. Upon complextion, the $\mathrm{H}_{10}$ signal of pyrenyl ring is downfield shifted $(9.29 \mathrm{ppm})$ while the pyridyl signals are upfield shifted $(7.60-5.94 \mathrm{ppm})$. This result implies the engagement of pyridyl nitrogen atom in coordination sphere of palldium. The two protons of methylene group attached to pyrenyl and pyridyl rings are no longer equivalent, giving rise to doublet signals (5.42ppm and 5.12ppm) due to spin coupling between them. Similar to the pattern observed in Pd-PyEt2, the four protons of ethylenediamine moiety are manifested in the spectrum as two doublets (4.55ppm and $3.10 \mathrm{ppm}$ ) and two triplets (4.43ppm and $3.70 \mathrm{ppm})$. This reveals a very crowded coordination sphere, making further signal splitting to each separate proton. Another piece of evidence confirms that the connection of pyridyl nitrogen to palladium is 
the four multiplets corresponding to four methylene protons of ethyl groups. This may suggest a square pyramidal configuration of the complex as pyridyl ring could be in closer appoach to ethyl groups.

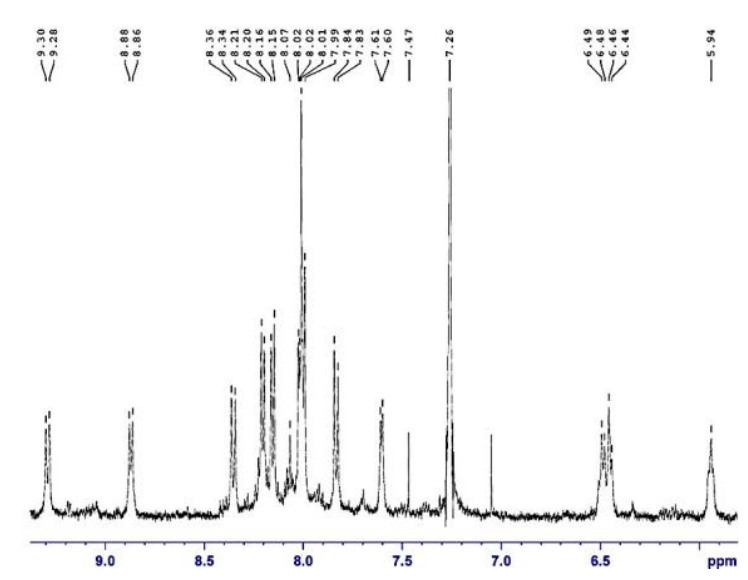

a)

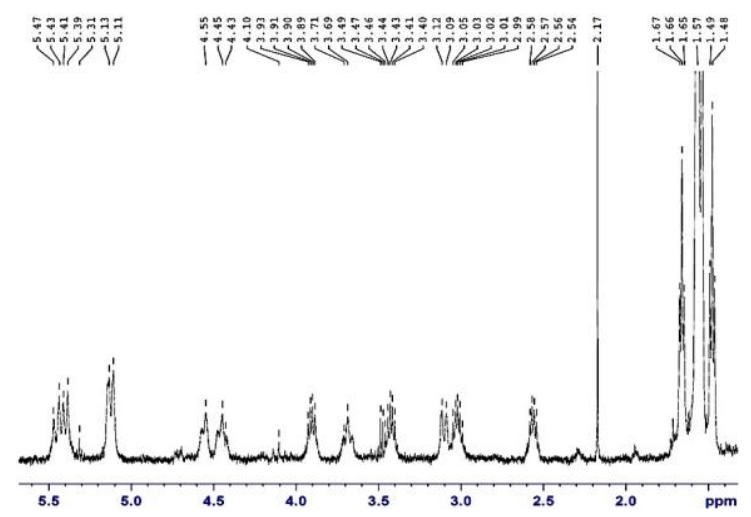

b)

Figure 2. ${ }^{1} \mathrm{H}$ NMR spectrum of Pd-PyEt3 in $\mathrm{CDCl}_{3}$.

\section{Conclusion}

In summary, a series of ligand PyEt1, PyEt2, and PyEt3 which contain pyrenyl core have been synthesized and characterized. The pre-organized three nitrogen donor atoms in PyEt3 took part in unusual five-coordinate mode with palladium(II) which was revealed by ${ }^{1} \mathrm{H}$ NMR spectroscopic results. Ongoing studies about luminescent properties of this complex are presently underway in our laboratories.

\section{Acknowledgments}

This research is funded by Vietnam National Foundation for Science and Technology Development (NAFOSTED) under grant number 104.03-2014.49.

\section{References}

[1] M. Zhao, X. Zhou, J. Tang, Z. Deng, X. Xu, Z. Chen, X. Li, L. Yang, L.-J. Ma, Pyrene excimerbased fluorescent sensor for detection and removal of $\mathrm{Fe}^{3+}$ and $\mathrm{Pb}^{2+}$ from aqueous solutions, Spectrochim Acta A. 173 (2017) 235-240. https://doi.org/10.1016/j.saa.2016.09.033.

[2] H. Turhan, E. Tukenmez, B. Karagoz, N. Bicak, Highly fluorescent sensing of nitroaromatic explosives in aqueous media using pyrene-linked PBEMA microspheres, Talanta. 179 (2018) 107 114. https://doi.org/10.1016/j.talanta.2017.10.061.

[3] N. Li, L. Qi, J. Qiao, Y. Chen, Ratiometric Fluorescent Pattern for Sensing Proteins Using Aqueous Polymer-Pyrene $/ \gamma$-Cyclodextrin Inclusion Complexes, Anal. Chem. 88 (2016) 1821-1826. https://doi.org/10.1021/acs.analchem.5b04112.

[4] G. Sivaraman, T. Anand, D. Chellappa, Pyrene based selective-ratiometric fluorescent sensing of zinc and pyrophosphate ions, Anal. Methods 6 (2014) 2343-2348. https://doi.org/10.1039/c3ay 42057d.

[5] D. Fernández, M.I. García-Seijo, T. Kégl, G. Petőcz, L. Kollár, M.E. García-Fernández, Preparation and Structural Characterization of Ionic Five-Coordinate Palladium(II) and Platinum(II) Complexes of the Ligand Tris[2(diphenylphosphino)ethyl]phosphine. Insertion of $\mathrm{SnCl}_{2}$ into $\mathrm{M}-\mathrm{Cl}$ Bonds $(\mathrm{M}=\mathrm{Pd}, \mathrm{Pt})$ and Hydroformylation Activity of the $\mathrm{Pt}-\mathrm{SnCl}_{3}$ Systems, Inorg. Chem. 41 (2002) 4435-4443. https://doi.org/10.1021/ic020006k. 